\title{
Research Status and Development Trend of Chinese Medicine Chewing Gum
}

\author{
YAN Ni ${ }^{1 a, *}$, WEN Ya ${ }^{1, b}, T_{U}$ Xi-mei ${ }^{1, c}$ \\ ${ }^{1}$ School of Management, Hubei University of Traditional Chinese Medicine; Hubei Research Center for Traditional Chinese Medicine \\ Development, Wuhan, China
}

\begin{abstract}
At present, chewing gum plays a certain role in the medical field. With the increasing demand for health care functional products, Chinese Medicine Chewing Gum is gradually developing. In this paper, the function, formulation and preparation technology of Chinese medicine chewing gum are summarized and analyzed in detail based on literature and patent, expecting that the chewing gum will be given more value and meaning in the future.
\end{abstract}

\section{1 introduction}

Chewing gum is a kind of candy, which uses natural gum or glycerin resin as the main component of the colloid and is made by blending and pressing with syrup, mint, and sweeteners for people to chew ${ }^{[1]}$. According to relevant records, chewing gum has a long history, humans have a habit of chewing natural resin long ago, that is, the most primitive "chewing gum". However, most chewing gums on the market contain various kinds of sweeteners and additives, and the chewing movement and secretion caused by chewing gum have certain effects on oral and gastrointestinal health, etc., it has also been the subject of extensive discussion among doctors, experts and scholars. Therefore, the functional chewing gum containing various health factors has gradually developed into a new trend in the market. In China, the rapid development of functional chewing gum in recent decades has prompted people to have a higher demand for the efficacy of chewing gum. Most functional chewing gums have won the favor of some consumers by adding health factors, trace elements, vitamins, new gels and other new materials. The role of chewing gum in the medical field has gradually emerged, and traditional Chinese medicine chewing gum has emerged. Traditional Chinese medicine gum is mainly composed of Chinese herbal medicine, which contains highly effective components and relatively few chemical additives. The extracted effective components have certain protective effects on human health. In this paper, the related research on Chinese medicine chewing gum was carried out to explore the related innovations in the formulation and efficacy of Chinese medicine chewing gum, the progress and development trend of the preparation technology in different periods, and to understand the efficacy study of Chinese medicine chewing gum in different fields, for example, in the field of health care, medicine and so on, to clarify the market of Chinese Medicine Chewing Gum and its future development direction.

\section{The efficacy of traditional Chinese medicine chewing gum}

\subsection{The basic function of chewing gum}

Traditional Chinese medicine chewing gum has the same functions as ordinary chewing gum, such as eliminating bad breath, keeping oral cavity fresh, promoting saliva secretion and so on. Chewing gum after a meal can not only clean the teeth, but also the secreted salivary enzymes can decompose harmful substances that enter the oral cavity, play a role in cleaning the oral cavity, preventing dental caries, and reducing dental stains. The repeated grinding action of chewing gum can stimulate the teeth and massage the mouth while effectively exercising the jaw, masseter muscle and teeth, which is very beneficial to periodontal health ${ }^{[2]}$.

Chewing Gum, which mimics food intake, is thought to be a form of sham feeding. The physiological mechanism of promoting the recovery of intestinal motility may be the activation of the "head-vagus nerve" reflex $^{[3]}$, and the salivation of saliva caused by chewing gum through the activation of Vagus nerve, which reflexively stimulates the secretion of gastrointestinal fluids. More importantly, the secretion of digestive juice can increase the patient's appetite, improve the patient's emotional state, and relieve tension. Therefore, it is suitable for some patients who require food fasting and liquid fasting after surgery, because chewing gum will not cause food to enter the gastrointestinal tract and will not cause related adverse reactions.

Chewing Gum can speed up the heart movement, increase the blood supply to the head, thus improving the 
brain vitality and thinking ability, thus enhancing memory and attention ${ }^{[4]}$. In addition, chewing gum can also protect your ears. Chewing gum during take-off and landing stages can also avoid "aviation ear damage."

In addition, chewing gum can increase energy consumption, accelerate fat metabolism, promote facial muscle movement, increase blood circulation, and have the effects of beauty and weight loss. Chewing Gum can be used as a drug carrier to improve the acceptance of people, and the application of Chinese medicine chewing gum in medicine is numerous, especially for postoperative rehabilitation and health care of patients.

\subsection{Functional chewing gum}

At present, there are few researches on the combination of Chinese herbal medicine and chewing gum for the prevention and treatment of diseases, and more functional chewing gum should be developed to meet people's dual needs of chewing gum taste and health care. Such as blood pressure health care chewing gum, heat-clearing detoxification, anti-bacterial anti-inflammatory chewing gum, environmental protection chewing gum.

As of July 17,2020, a total of 33 articles were retrieved on CNKI with "Chinese Medicine Chewing Gum" as the key word, and 6 articles were mainly about the function of Chinese medicine chewing gum except advertisement and low relevance. In Wanfang, 139 patents were found, including 137 patents for invention, 2 patents for utility model, and 128 patents that highlighted the function of traditional Chinese Medicine Chewing Gum.

According to the main functions of chewing gum, some representative formulas are selected, as shown in Table 1.

Table 1 Efficacy and formulation of typical Chinese medicine chewing gum

\begin{tabular}{|c|c|c|}
\hline Main effect & $\begin{array}{c}\text { Main } \\
\text { ingredients }\end{array}$ & Literature. \\
\hline $\begin{array}{l}\text { Antibacterial, } \\
\text { anticancer, and } \\
\text { oral care }\end{array}$ & $\begin{array}{c}\text { Gum Base, } \\
\text { D-Sorbitol, } \\
\text { hexahydro } \\
\beta \text {-acid, xylitol } \\
\text { syrup, food } \\
\text { grade glycerin, } \\
95 \% \text { food grade } \\
\text { alcohol, essence, } \\
\text { mint, } \\
\beta \text {-cyclodextrin, } \\
\text { etc. }\end{array}$ & $\begin{array}{l}\text { Development of } \\
\text { lupulus }\end{array}$ \\
\hline $\begin{array}{l}\text { Anti-fatigue } \\
\text { and refreshing } \\
\text { brain }\end{array}$ & $\begin{array}{l}\text { Ginsenoside, } \\
\text { Puerarin, } \\
\text { polysaccharide, } \\
\text { volatile oil, } \\
\text { terpenoids, etc. }\end{array}$ & $\begin{array}{l}\text { Development of } \\
\text { Chinese } \\
\text { medicine health } \\
\text { gum. }\end{array}$ \\
\hline $\begin{array}{l}\text { Fresh breath } \\
\text { and protect the } \\
\text { environment }\end{array}$ & $\begin{array}{c}\text { Schisandra } \\
\text { chinensis, } \\
\text { Semen Ziziphi } \\
\text { Spinosae, } \\
\text { stevioside, gum } \\
\text { base, essence, }\end{array}$ & $\begin{array}{l}\text { Research on } \\
\text { green gum with } \\
\text { bamboo shoots. }\end{array}$ \\
\hline
\end{tabular}

\begin{tabular}{|c|c|c|}
\hline & Glycerin, etc. & \\
\hline Mine calming & $\begin{array}{l}\text { Schisandra, } \\
\text { jujube seed, } \\
\text { stevioside, gum } \\
\text { base, flavor, } \\
\text { glycerin, etc. }\end{array}$ & $\begin{array}{l}\text { Soothing and } \\
\text { refreshing } \\
\text { chewing gum }\end{array}$ \\
\hline $\begin{array}{c}\text { New flavor of } \\
\text { white tea }\end{array}$ & $\begin{array}{l}\text { White tea } \\
\text { powder, ganache } \\
\text { powder, white } \\
\text { cardamom } \\
\text { powder, incense } \\
\text { powder, etc. }\end{array}$ & $\begin{array}{l}\text { White tea gum } \\
\text { and its } \\
\text { production } \\
\text { method. }\end{array}$ \\
\hline $\begin{array}{l}\text { Activating } \\
\text { blood to } \\
\text { remove blood } \\
\text { stasis, clearing } \\
\text { menstruation } \\
\text { and swelling, } \\
\text { promoting } \\
\text { blood } \\
\text { circulation, } \\
\text { regulating } \\
\text { blood, } \\
\text { nourishing } \\
\text { blood, } \\
\text { lowering } \\
\text { blood fat, } \\
\text { softening } \\
\text { blood vessels }\end{array}$ & $\begin{array}{l}\text { Safflower seed } \\
\text { oil, malic acid, } \\
\text { citric acid, } \\
\text { sucrose, } \\
\text { glucose, gum } \\
\text { base, etc. }\end{array}$ & $\begin{array}{c}\text { Safflower } \\
\text { Women's } \\
\text { Chewing Gum }\end{array}$ \\
\hline $\begin{array}{l}\text { Prevent and } \\
\text { treat sore } \\
\text { throat, } \\
\text { hoarseness, } \\
\text { and mouth } \\
\text { sores }\end{array}$ & $\begin{array}{l}\text { Honeysuckle, } \\
\text { mint, stevioside, } \\
\text { gum base, gum, } \\
\text { glycerin, etc. }\end{array}$ & $\begin{array}{l}\text { Throat voiceless } \\
\text { chewing gum }\end{array}$ \\
\hline hypotensive & $\begin{array}{l}\text { Ginkgo biloba, } \\
\text { eucommia, } \\
\text { salvia } \\
\text { miltiorrhiza, } \\
\text { golden } \\
\text { buckwheat, } \\
\text { sweeteners, gum } \\
\text { base, spices, } \\
\text { pigments, blood } \\
\text { pressure } \\
\text { lowering } \\
\text { substances, etc. }\end{array}$ & $\begin{array}{l}\text { Lowering blood } \\
\text { pressure } \\
\text { chewing gum }\end{array}$ \\
\hline $\begin{array}{l}\text { Reduce fat and } \\
\text { lose weight }\end{array}$ & $\begin{array}{c}\text { Chinese } \\
\text { medicine } \\
\text { dosage, } \\
\text { stevioside, gum } \\
\text { base, spices, etc. }\end{array}$ & $\begin{array}{l}\text { Lipid-lowering } \\
\text { and weight-loss } \\
\text { chewing gum } \\
\text { and its } \\
\text { preparation } \\
\text { method }\end{array}$ \\
\hline $\begin{array}{l}\text { Relieve the } \\
\text { attack of } \\
\text { rhinitis }\end{array}$ & $\begin{array}{c}\text { Addition and } \\
\text { subtraction of } \\
\text { Yupingfeng San, } \\
\text { add ginseng, } \\
\text { Yunzhi, } \\
\text { Angelica } \\
\text { dahurica, mint, } \\
\text { licorice, etc. }\end{array}$ & $\begin{array}{l}\text { Chronic rhinitis } \\
\text { chewing gum }\end{array}$ \\
\hline
\end{tabular}

Out of the 128 patent applications, 124 are about gum formulations, mainly dealing with the three functions of guns: prevention and health care, freshening breath, treatment and detoxification. It can be seen that the 
product development of Chinese medicine chewing gum mainly focuses on formula innovation to meet the people's pursuit of both efficacy and taste quality.

\subsection{Research on traditional Chinese medicine chewing gum in different fields}

This paper summarizes the research achievements of Chinese medicine chewing gum over the years from the aspects of literature and patent achievements, and generalizes its author, year and core viewpoints. The literature is summarized as follows:

Table 2 Literature-research results

\begin{tabular}{|c|c|c|c|}
\hline Core view & Author & Years & $\begin{array}{c}\text { Representative } \\
\text { literature }\end{array}$ \\
\hline $\begin{array}{l}\text { Mainly } \\
\text { research the } \\
\text { formula of } \\
\text { chewing } \\
\text { gum, and } \\
\text { make } \\
\text { innovations } \\
\text { in taste and } \\
\text { dosage form }\end{array}$ & Han Wangrong & $1990 \mathrm{~s}$ & $\begin{array}{l}\text { Brief } \\
\text { introduction to } \\
\text { the formulation } \\
\text { of bubble gum } \\
\text { and chewing } \\
\text { gum abroad }\end{array}$ \\
\hline \multirow{2}{*}{$\begin{array}{l}\text { Functional } \\
\text { chewing } \\
\text { gum and } \\
\text { health-care } \\
\text { chewing } \\
\text { gum began } \\
\text { to rise } \\
\text { slowly }\end{array}$} & $\begin{array}{c}\text { Zhou Weiwei, } \\
\text { Chen Zhong, } \\
\text { Wan Juan }\end{array}$ & \multirow[t]{2}{*}{$2000-2010$} & $\begin{array}{l}\text { Development } \\
\text { of a new } \\
\text { anti-fatigue } \\
\text { chewing gum }\end{array}$ \\
\hline & $\begin{array}{l}\text { Li Weijie, Chen } \\
\text { Chunsheng }\end{array}$ & & $\begin{array}{l}\text { Development } \\
\text { of Pu'er Tea } \\
\text { Flavored } \\
\text { Chewing Gum } \\
2009\end{array}$ \\
\hline \multirow{2}{*}{$\begin{array}{l}\text { There are } \\
\text { many types } \\
\text { of } \\
\text { functional } \\
\text { chewing } \\
\text { gum and } \\
\text { health-care } \\
\text { chewing } \\
\text { gum. The } \\
\text { role of } \\
\text { chewing } \\
\text { gum in the } \\
\text { medical } \\
\text { field is } \\
\text { beginning } \\
\text { to be } \\
\text { revealed. In } \\
\text { China, } \\
\text { Wrigley has } \\
\text { the largest } \\
\text { market } \\
\text { share }\end{array}$} & $\begin{array}{c}\text { Xu Huaxing, } \\
\text { Zhong Bin, Yi } \\
\text { Min, Li } \\
\text { Xiujuan, Wang } \\
\text { Xiaoping } \\
\end{array}$ & \multirow[t]{2}{*}{$2010-2015$} & $\begin{array}{c}\begin{array}{c}\text { Effect of } \\
\text { chewing }\end{array} \\
\text { sugar-free gum } \\
\text { on plaque index } \\
\text { in adults } 2010 \\
\end{array}$ \\
\hline & Wang Jiaping & & $\begin{array}{l}\text { Research and } \\
\text { production of } \\
\text { chrysanthemum } \\
\text { health chewing } \\
\text { gum } 2014\end{array}$ \\
\hline $\begin{array}{l}\text { The role of } \\
\text { chewing } \\
\text { gum in the } \\
\text { medical } \\
\text { field }\end{array}$ & $\begin{array}{l}\text { Wen Jizhen, } \\
\text { Tang Shurong }\end{array}$ & $2015-2020$ & $\begin{array}{l}\text { Study on the } \\
\text { application of } \\
\text { exercise } \\
\text { intervention } \\
\text { combined with } \\
\text { chewing gum } \\
\text { in colonoscopy } \\
\text { and bowel }\end{array}$ \\
\hline
\end{tabular}

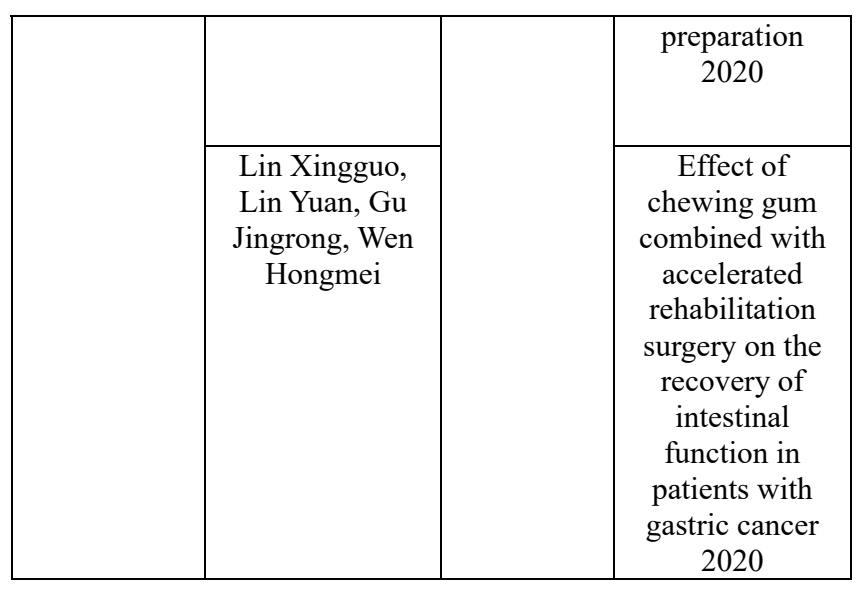

The patent achievements are organized as follows:

Table 3 Patents-research results

\begin{tabular}{|c|c|c|c|}
\hline Core view & Author & years & $\begin{array}{l}\text { Representative } \\
\text { patent }\end{array}$ \\
\hline \multirow{3}{*}{$\begin{array}{l}\text { Pay more } \\
\text { attention to } \\
\text { the } \\
\text { production } \\
\text { and } \\
\text { preparation } \\
\text { methods of } \\
\text { health } \\
\text { chewing } \\
\text { gum }\end{array}$} & $\begin{array}{c}\text { Li } \\
\text { Zhenchao, } \\
\text { Zhan } \\
\text { Huixin, }\end{array}$ & \multirow{3}{*}{$1990 \mathrm{~s}$} & $\begin{array}{l}\text { Production method } \\
\text { of health chewing } \\
\text { gum }\end{array}$ \\
\hline & $\begin{array}{l}\text { Wang } \\
\text { Yanhua }\end{array}$ & & $\begin{array}{l}\text { Chewing gum } \\
\text { containing Chinese } \\
\text { medicine and } \\
\text { preparation } \\
\text { method thereof }\end{array}$ \\
\hline & $\begin{array}{l}\text { Lin Weiwei, } \\
\text { Wang } \\
\text { Guixin }\end{array}$ & & $\begin{array}{c}\text { Manufacturing } \\
\text { method of series } \\
\text { Chinese medicine } \\
\text { health-care } \\
\text { chewing gum } \\
\end{array}$ \\
\hline \multirow{3}{*}{$\begin{array}{l}\text { Health Gum } \\
\text { and efficacy } \\
\text { gum were } \\
\text { the main } \\
\text { research } \\
\text { methods in } \\
\text { this period }\end{array}$} & $\begin{array}{l}\text { Pan } \\
\text { Yinghong }\end{array}$ & \multirow{3}{*}{$\begin{array}{l}2000- \\
2010\end{array}$} & $\begin{array}{c}\text { Anti-radiation } \\
\text { health chewing } \\
\text { gum }\end{array}$ \\
\hline & $\begin{array}{c}\text { Sun } \\
\text { Jieguang }\end{array}$ & & $\begin{array}{l}\text { Chinese medicine } \\
\text { beauty health } \\
\text { chewing gum }\end{array}$ \\
\hline & $\begin{array}{c}\text { Chen } \\
\text { Xingwen }\end{array}$ & & $\begin{array}{c}\text { Sugar-free } \\
\text { American Ginseng } \\
\text { Health Chewing } \\
\text { Gum }\end{array}$ \\
\hline \multirow{3}{*}{$\begin{array}{c}\text { The } \\
\text { research on } \\
\text { functional } \\
\text { chewing } \\
\text { gum is } \\
\text { gradually } \\
\text { increasing, } \\
\text { and the role } \\
\text { of chewing } \\
\text { gum in the } \\
\text { medical } \\
\text { field is } \\
\text { gradually } \\
\text { revealed }\end{array}$} & $\begin{array}{c}\text { Tang } \\
\text { Zeguang }\end{array}$ & \multirow{3}{*}{$\begin{array}{l}2010- \\
2015\end{array}$} & $\begin{array}{l}\text { Anti-inflammatory } \\
\text { and analgesic } \\
\text { Chinese medicine } \\
\text { chewing gum }\end{array}$ \\
\hline & Cui Ziyang & & $\begin{array}{l}\text { Chewing gum for } \\
\text { treating chronic } \\
\text { pharyngitis }\end{array}$ \\
\hline & Qiu Cailian & & $\begin{array}{c}\text { A kind of } \\
\text { hangover chewing } \\
\text { gum }\end{array}$ \\
\hline $\begin{array}{l}\text { Fruit-flavor } \\
\text { ed chewing } \\
\text { gum and } \\
\text { Chinese } \\
\text { medicine } \\
\text { chewing }\end{array}$ & Lu Xuefeng & $\begin{array}{l}2015- \\
2020\end{array}$ & $\begin{array}{l}\text { Preparation } \\
\text { method for } \\
\text { producing } \\
\text { health-care } \\
\text { chewing gum by } \\
\text { using blueberry }\end{array}$ \\
\hline
\end{tabular}




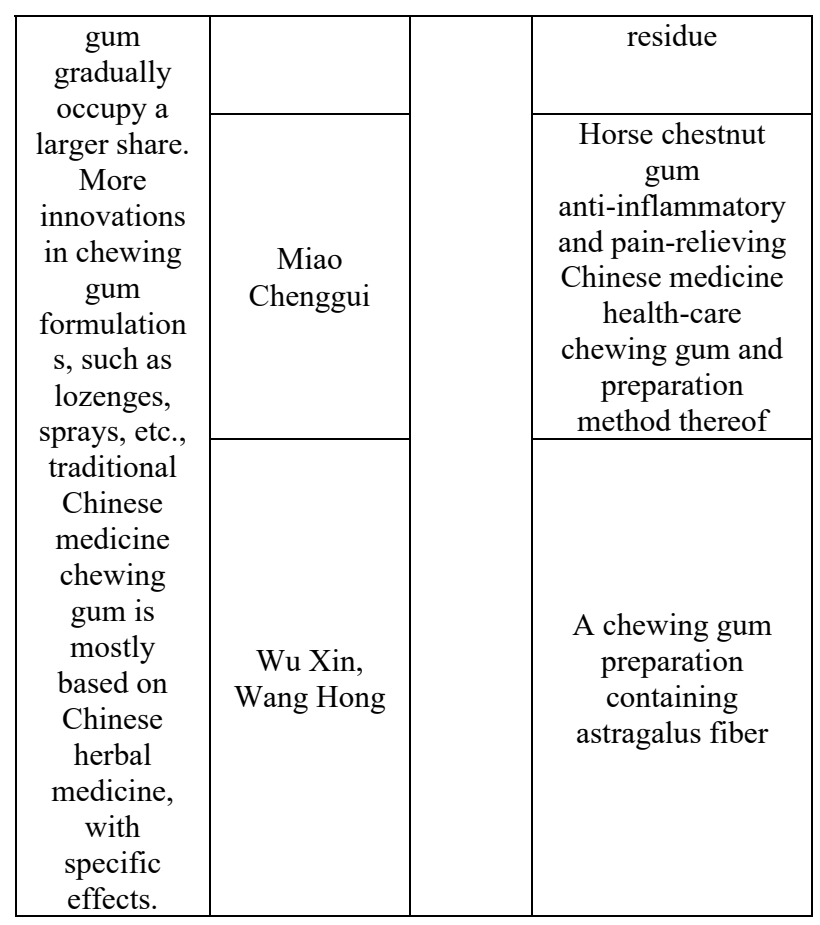

It can be seen that chewing gum is changing from a health-care type to a multi-function type, and it has been well developed in the fields of life, medicine, and biology, bringing more product choices to the market.

\section{Preparation technology of traditional Chinese medicine chewing gum}

\subsection{The technological process of traditional Chinese medicine chewing gum}

Different formulations of traditional Chinese medicine chewing gum have different preparation processes. Zhang Jinwei et al. ${ }^{[5]}$ have gone through a series of processes in the preparation of the new gum, first, the configuration of auxiliary materials such as tea polyphenols, honeysuckle, zinc gluconate; secondly, the preparation of gum bases with butyl rubber, hydrogenated rosin glyceride, paraffin wax and tallow; then, it is heated and softened, the gum base and the auxiliary materials are mixed in the incubator, so as to squeeze out a ribbon-shaped sugar embryo with tight organization and smooth surface; finally, the sugar slices are cut into shapes and packaged in waxed aluminum box paper. The development of Qingyan chewing gum by $\mathrm{Li}$ Nan and Yang Ming [6] experienced the crushing and mixing of Borneol, Catechu and Indigo Naturalis, the crushing of sucrose, the softening treatment of gum base, the full mixing and extrusion of ingredients, and the cutting and shaping of the gum, at the temperature of about $20^{\circ} \mathrm{C}$, the relative humidity is less than $55 \%$ when cooling aging, the final packaging process. Yu Peili et al. [7] experienced four stages in the preparation of yellow tea gum-free chewing gum, such as preparation of Yellow Tea extract and pretreatment of raw materials, sugar boiling and flavor regulation, cooling back sand and pouring molding, demoulding packaging and finished product detection. Zhang Zhong, Yang Mei ${ }^{[8]}$ adopted the technological process of aloe juice preparation, Zein preparation, gum base pretreatment, ingredient mixing, blending gum base and ingredient materials, and packaging to develop aloe chewing gum. Production process is roughly the same, but the specific raw materials used, the formula and so on are different.

At present, most of the chewing gum on the market is similar to the production process, but there are differences according to the pharmacology and properties of Chinese medicine in each formula. Some prescriptions require that Chinese medicines must be decocted after decoction. "Post-decocting" means decocting the medicine for ten minutes and then putting it into the medicine pot, because some Chinese medicines are not effective for a long time. At the same time, for some volatile medicinal materials, if the pot is not covered and the lid is left open, the efficacy will be greatly reduced. Generally, they are medicines such as peppermint, sesame leaves, and hummus. The decoction time of some medicinal materials should not be too long, such as some tonic drugs, ginseng, velvet antler, American ginseng, etc., which need to be covered with a lid and decocted slowly over a low fire for a long time to fully decoct the effective ingredients.

Due to the special bitter and astringent taste of Chinese medicine in Chinese medicine chewing gum, it is necessary to improve the taste of Chinese medicine. Therefore, the orthogonal test of the best formula was carried out to test the factors that affect the chewing quality, flavor, texture and taste of Chinese medicine chewing gum, to get the best ratio.

\subsection{The solution to the stickness and sand return}

According to GB/T29605-2013, GB5009.3-2016 and GB4789-2016, and with reference to the characteristics and quality standards of chewing gum in the same trade, the sensory, physicochemical and microbiological indexes of health chewing gum were determined. The sensory indexes include color, flavor and shape: The chewing gum body has a complete appearance, smooth appearance, uniform color, moderate aroma, no peculiar smell, good chewing toughness, non-sticky teeth, etc.. The sensory index can be assessed by professional assessment such as 9-person scoring method. Physical and chemical indexes include water content and other quality indexes. The food microbiological indicators promulgated by the Ministry of Health of China include the total number of colonies, coliforms and pathogenic bacteria, among which pathogens must not be contained.

Stickness is the main quality change problem of chewing gum. Sand returning is the main quality change of chewing gum. In order to restrain the situation of stickness and sand returning, the processing technology and external environment of Chinese medicine chewing gum are strict. The solutions to prevent the sand return are: 1 . reduce the relative humidity and temperature of the storage environment; 2. make the sugar and Syrup a proper proportion; 3 . reduce the moisture: the lower the moisture, the higher the viscosity, and the more it can 
prevent sand return; 4. Try not to agitate at high temperature: Don't agitate the massecuite excessively at high temperature after boiling, otherwise the viscosity of the syrup will decrease and cause sanding; 5. Minimize the holding time: long holding time is easy to return sand; 6 . The returning material of returning sand can not be added into the sugar paste. The returned material of the returned sand acts as a sucrose seed crystal in the massecuite, resulting in the return of the entire sugar mass; (7) Other factors, such as the type and quality of granulated sugar and syrup; the different conditions of product packaging and preservation.

\section{Future and prospects}

\subsection{Future research directions of traditional Chinese medicine chewing gum}

Under the background of the good development trend of the big health industry, Chinese medicine chewing gum is gradually accepted by the public, the research results are more abundant, but there are few products that are really listed and have a wider audience. The research on the formula and efficacy of Chinese medicine chewing gum should be deepened, and new market strategy should be made, multi-channel sales and market share should be expanded.

The production of sugar-free chewing gum to the majority of consumers has brought good news. And Sugar Free Gum doesn't provide the carbohydrates needed for plaque metabolism, reducing the production of acidic compounds that promote Remineralisation of teeth, which greatly reduces the risk of dental caries ${ }^{[9]}$. In the future, sugar-free chewing gum will be an important research point.

In addition, the problem of gum cleaning has been a difficult problem, the current commonly used gum base softening adhesion is greater, in natural conditions are difficult to degrade. Therefore, the use of biodegradable green gum-based chewing gum has become an important direction of chewing gum development ${ }^{[10]}$.

\subsection{In-depth development of traditional Chinese medicine chewing gum}

Ordinary chewing gum can only play a short period of time to clean up the mouth, remove bad breath, can not meet people's growing other functional needs, the development of new features of chewing gum gradually attention. In recent years, the effect of chewing gum in postoperative treatment has been a hot topic, and it has been recognized in clinical medicine and rehabilitation. In the future, research on such applications will be increased.

The geographical environment is very complex, and the soil and water, climate, sunshine, biological distribution are not exactly the same, therefore, the quality of the medicine itself and its therapeutic effects are also significantly different. Most of the Chinese medicinal materials in Chinese medicine chewing gum are selected genuine medicinal materials. They can develop local resources of Chinese medicinal materials and cooperate with poor areas, which are not only in response to the national 13th FIVE-YEAR PLAN TO FIGHT POVERTY, also can realize the producer, the intermediate business multi-party win-win situation.

\section{Conclusion}

The Times are advancing, science and technology are innovating, and people's needs are becoming more and more complex. Today's chewing gum is no longer a substitute for toothpaste. It continues to innovate in terms of taste, formula, efficacy, and preparation technology, and has different researches for ordinary consumers and special populations. As the carrier of medicine, Chinese medicine chewing gum will be given more significance in the future. Chewing gums prepared for anti-alcoholism, smoking cessation, contraception, and promotion of postoperative recovery, etc., are the crystallization of people's thoughts and wisdom. In the future, it is expected that chewing gum can be given more value and meaning!

\section{References}

1. Zhang Miao, Xia Wei, Song Yanan, Ma Xing, Ye Ying. Development of Traditional Chinese Medicine Health-Care Chewing Gum[J]. Food \& Fermentation Tec., 2019, 55(04): 87-91.

2. Chewing Gum Can Temporarily Improve Memory $[\mathrm{J}]$. Chinese Archives of Traditional Chinese Medicine, 2010, 28(04):689.

3. Qing Yang. Research and Development of New Chewing Gum Anti-Alcoholic Effects to Double Product Advantages and Expand into A Big Market [J]. Modern Marketing (Chuangfu Information Edition), 2009(04):50.

4. Zhao Cong, Zhao Bing, Cui Chao, Yao Mo, Gong Jiang, Ni Shifeng. The Health Care Value of Chewing Gum[J]. Ningxia Journal of Agriculture and Forestry Science and Technology, 2011, 52(11): $39-4080$.

5. Zhang Jinwei, Li Hujun, Zhou Hongyuan, Hou Dajun. Development of A New Type of Halitosis Chewing Gum $[\mathrm{J}]$. Food \& Fermentation Tec., 2011,47(02):86-89.

6. Li Nan, Yang Ming. Development of Throat-clearing Chewing Gum[J]. Science and Technology of Food Industry, 2006(01):107-108.

7. Yu Peili. Research on The Development of Yellow Tea Non-Gum Base Chewing Gum[D]. Zhejiang A\&F University, 2019.

8. Zhang Zhong, Yang Mei. Development of Aloe Nutrition and Health Chewing Gum[J]. Food Industry Science, 2003(02): 58-60.

9. Dong Ying, $\mathrm{Hu}$ Deyu. Effects of Additives in Sugar-Free Gum on Dental Health[J]. Journal of Oral Medicine Research, 2013, 29(11): 1083-1085. 
10. Yu Meirong. Research on Bamboo Shoot Environmental Protection Chewing Gum[D]. Central South University of Forestry and Technology, 2007. 